\title{
EVALUATION OF CERTAIN CHEMICAL AND BIOCHEMICAL COMPOUNDS ON RED SPIDER MITE, TETRANYCHUS URTICAE KOCH (ACARINA : TETRANYCHIDAE) INFESTING COTTON PLANTS
}

\author{
ABBASSEY, M. R. A. ${ }^{1}$, S. A. MOSTAFA ${ }^{2}$, M. A. MOSTAFA ${ }^{1}$, \\ A. A. H. MANGOUND ${ }^{2}$ AND S. A. A.OSMAN ${ }^{2}$ \\ 1 Faculty of Agriculture, Al-Azher University \\ 2 Plant Protection Research Institute, ARC, Dokki, Giza
}

(Manuscript received 27 May 2008)

\begin{abstract}
The tetranychid mite is considered one of the important mite pests attacking cotton plants in Egypt. The present work was carried out to study the efficacy of the tested compounds against the two-spotted spider mite, Tetranychus urticae under field conditions.

First season (2005):

The cotton plants were sprayed by using the recommended concentration of seven compounds, namely (agrin, Vertemic, hexaflumuron, Super Misrona Oil, Micronized Sulfur, and Liquid Sulfur) to study the effectiveness on the adult stages of the twospotted spider mite, Tetranychus urticae.

Vertemic gave highly reduction percent $(85.11 \%)$ in infestation against the adult stages of $T$. urticae, while Agrin, flufenoxuron, hexaflumuron, Super Misrona Oil, Micronized Sulfur, and Liquid Sulfur gave approximately similar results $66.20,77.10,72.16$, $70.96,71.73$ and 70.29 , respectively.

Second season (2006):

Vertemic gave highly percent reduction (88.32\%) in infestation against the adult stages of $T$. urticae, while, agrin, flufenoxuron, hexaflumuron, Super Misrona Oil, Micronized Sulfur, and Liquid Sulfur gave approximately similar results $69.17,83.67,75.71$, $75.10,69.15$ and 72.02 , respectively.
\end{abstract}

\section{INTRODUCTION}

The tetranychid mites are the most important pests and plant feeders of considerable economic important attacking field crops, fruits and vegetable crops (Wafa et al., 1968). The two spotted- red spider mite, Tetranychus urticae Koch (Acarina : Tetranychidae), is a major economic pest attacking field crops especially cotton plants, vegetables as well as strawberry, cucumber and cantaloupe and horticultural crops in addition to the medicinal plants.

The total cotton cultivated area in Egypt reached 436.719 Feddan distributed in a good soil. Since the discovery of the injury of cotton by spider mites at the beginning of the second decade of the twentieth century, the spider mite infestation has become more frequent and more widespread. The outbreak of spider mites is due to 
destruction of spider mite predators by the pesticides, together with the tendency of this mite to develop resistance. These mites usually feed on the leaves injuring the epidermis and resulting in blotching stippling or bronzing and sometime accompanied by leaf fall. Some of the species are most specific but the majority are phytophagous and has a wide range of hosts. Severe mites feeding result in economic reduction in the quality and quantity of crop production.

Continuous use of acute acaricides has caused serious suppression in natural economic population, residual contamination of human foods, mammalian toxicity and pollution of the environment. Therefore, new approaches in pest control, particularly use of natural compounds has received recently a considerable attention, in different localities of the world.

The present work aimed to evaluate the efficacy of different compounds against the two-spotted spider mite, Tetranychus urticae under field conditions.

\section{MATERIALS AND METHODS}

\section{Experimental design:}

The present study was conducted on cotton plants (Giza 80) grown in Beni-Sueif Governorate. Two experiments were conducted during May of the two successive years 2005 and 2006 when pest population density was high. An area of one feddan was divided into eight plots, each of approximately $50 \mathrm{~m}^{2}$. The plots were arranged in complete randomized block with four replicates for each treatment, and another four replicates as control. The plots were sprayed with different tested agents using a knapsack sprayer. Control plots were sprayed with water only.

One spray was conducted during each year on May. To evaluate the efficacy of tested compounds the number of adults was recorded at pre-treatment and after 3, 7, 14 and 21 days of treatment. Each sample consisted of 80 cotton leaves taken randomly form each plot. The sampled leaves were collected in paper bags and transferred directly to the laboratory for careful examination. Adult females were counted under a stereomicroscope, and both surfaces of each leaf were inspected.

\section{Tested compounds:}

The compounds used in the present experiments were:

\section{A. Agrin $32000 \mathrm{IU} / \mathrm{mg}$ (Bacillus thurengiensis var kurstakl):}

A commercial microbial products used in these trails in which the active ingredients based on bacterium Bacillus thurengiensis var kurstaki (Bt) formulated by BioAgro International, Egypt. 


\section{B. Vertemic 1.8\% EC (abamectin):}

A commercial product used in these trails in which the active ingredients based on formulated by International, Egypt.

\section{Consult $\mathbf{1 0 \%}$ EC (hexaflumuron):}

A commercial product used in these trails in which the active ingredients based on formulated by Dow AgroSciences, 9330 Zionsville Rd.Indianapolis, IN 46268-1054, USA.

\section{Cascade $10 \%$ EC (flufenoxuron):}

A water dispersible concentrate, formulated by American Cyanamid Co..

\section{E. Super Misrona oil 94\% EC (light mineral oil):}

Super Misrona oil miscible formulated by Masrona Co., containing $94 \%$ praffinic oil $\mathrm{w} / \mathrm{w}$ and $6 \%$ inert ingredients, unslufonated residue content reached $94 \%$.

\section{F. Micronized sulfur $80 \%$ WP:}

Micronized sulfur formulated by Kafr El-Zayat Co., containing $80 \%$ sulfur and $20 \%$ inert ingredients.

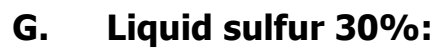

Liquid sulfur formulated by Kafr El-Zayat Co., containing 30\% sulfur and $70 \%$ inert ingredients.

\section{Statistical analysis:}

The reduction percentages of infestation by $T$. urticae were calculated according to the equation of Henderson and Tilton (1955). The data was subjected to analysis of variance (ANOVA) and the means were compared by L.S.D. test at 0.05 level, using SAS program (SAS, 1988).

\section{RESULTS AND DISCUSSION}

\section{First season (2005):}

The average maximum and minimum temperatures in the field were 33.46 and $17.63^{\circ} \mathrm{C}$ and the maximum and minimum relative humidity were 79.19 and $22.94 \%$, respectively.

The cotton plants were sprayed by using the recommended concentration of seven compounds, namely (Agrin, abamectin, flufenoxuron, hexaflumuron, Super Misrona Oil, Micronized Sulfur, and Liquid Sulfur) to study the effectiveness on the adult stages of the two-spotted spider mite, Tetranychus urticae Koch.

The average numbers of $T$. urticae pre-spraying counts were 145.00, 145.30, 146.50, 145.50, 144.25, 147.50 and 146.75 adults/leaf recorded in Agrin, abamectin, flufenoxuron, hexaflumuron, Super Misrona Oil, Micronized Sulfur, and Liquid Sulfur plots, respectively and reached 143.00 adults/leaf in control (Table, 1 ). 
EVALUATION OF CERTAIN CHEMICAL AND BIOCHEMICAL COMPOUNDS

ON RED SPIDER MITE, TETRANYCHUS URTICAE KOCH

(ACARINA : TETRANYCHIDAE) INFESTING COTTON PLANTS 
Table (2) 
Abamectin (Vertimec) gave highly reduction percent $(85.11 \%$ ) of population against the adult stages of $T$. urticae, while Agrin, flufenoxuron, hexaflumuron, Super Misrona Oil, Micronized Sulfur, and Liquid Sulfur gave approximately similar reduction rates, i.e. $66.20,77.10,72.16,70.96,71.73$ and 70.29, respectively (Table, 2).

The above mentioned results indicate that the efficacy of tested compounds was varied due to the nature of compounds and the concentrations used.

Statistical analysis in Table (1) showed highly significant differences between the average numbers of adults for T. urticae after application of seven compounds (Agrin, Vertemic, flufenoxuron, hexaflumuron, Super Misrona Oil, Micronized Sulfur, and Liquid Sulfur) after 3, 7, 15 and 21 days indicating ( $F=118.59,721.38,282.42$ and 591.04 at $\mathrm{P}<0.05)$, and $L S D=3.66,5.38,7.82$ and 7.04 , respectively.

The obtained results are agree with those obtained by several authors, Rote et al. (1981) studied the effectiveness of wettable sulfur and sulfur dust applied together with carbaryl with that of dicofol against Tetranychus cinnabarinus (Boisd.) on Hybrid4 cotton. Highest mortality was obtained in plots treated with $0.03 \%$ dicofol, and sulfur dust and $0.2 \%$ wettable sulfur plus $0.2 \%$ carbaryl were almost as effective, respectively. It was concluded that sulfur in both formulations appeared to be compatible with carbaryl in controlling the pest if used at the recommended dosages.

Mani et al. (2003) determine the suitable acaricide against Tetranychus urticae. They found that plants treated with $200 \mathrm{ml}$ flufenoxuron/ha showed maximum reduction in colonies per leaf (18.26\% in Mirandy and $35.76 \%$ in Arjuna). Percent reduction in infestation per leaf was highest after 30 days from spraying with $200 \mathrm{ml}$ flufenoxuron/ha (18.42\% in Mirandy and $26.48 \%$ in Arjuna). However, percent reduction in infestation per plant was highest in Mirandy (18.68\%) and Arjuna (19.34\%) when $200 \mathrm{ml}$ flufenoxuron/ha was sprayed.

\section{Second season (2006):}

The average maximum and minimum temperatures in the field were 33.08 and $19.01^{\circ} \mathrm{C}$ and the maximum and minimum relative humidity were 81.1 and $14.84 \%$, respectively.

The average numbers of $T$. urticae pre-spraying counts were $122.75,119.75,121.50$, 116.50, 119.75, 118.50 and 114.75 adults/leaf for Agrin, Vertemic, flufenoxuron, hexaflumuron, Super Misrona oil, Micronized sulfur, and Liquid sulfur adults/leaf, respectively but it reached 116.86 adults/leaf in control (Table, 3 ). 
EVALUATION OF CERTAIN CHEMICAL AND BIOCHEMICAL COMPOUNDS

ON RED SPIDER MITE, TETRANYCHUS URTICAE KOCH

(ACARINA : TETRANYCHIDAE) INFESTING COTTON PLANTS 
Also, Vertemic gave highly percent reduction $(88.32 \%)$ in infestation against the adult stages of $T$. urticae, while, Agrin, flufenoxuron, hexaflumuron, Super Misrona Oil, Micronized Sulfur, and Liquid Sulfur gave approximately similar reduction, showing 69.17, 83.67, 75.71, 75.10, 69.15 and 72.02, respectively (Table, 4).

As mentioned above the potency of different compounds varied due to the nature of compounds and the used concentrations.

Statistical analysis in Table (3) show that highly significant differences between the average numbers of adults for $T$. urticae after application of seven compounds (Agrin, Vertemic, flufenoxuron, hexaflumuron, Super Misrona Oil, Micronized Sulfur, and Liquid Sulfur) after 3, 7, 15 and 21 days were ( $F=187.05,253.93,135.83$ and 124.4 at $\mathrm{P}<0.05)$, and $\mathrm{LSD}=3.77,2.27,2.91$ and 3.49 , respectively.

The obtained results are agree with those obtained by several authors, Akashe (2004) tested sulfur at $0.2 \%$ against $T$. urticae infesting rose under field conditions. Sulfur gave lower efficacy (55.56\%). Nangia and Channa (1983) when 0.05-0.15\% sulfur and $0.002-0.01 \%$ dicofol were applied in sprays in field, mortality reached $80.7-$ $41.8 \%$ followed in $24 \mathrm{~h}$ in the pest Tetranychus /udeni Zacher and $14.47-24.85 \%$ in its predator Amblyseius tetranychivorus (Gupta).

\section{REFERENCES}

1. Akashe, V. B. 2004. Management of spotted spider mite (Tetranychus urticae Koch) of rose during summer season. J. Maharashtra Agric. Univ., 29(1): 96-97.

2. Hendrson, C.F. and E.W. Tilton. 1955. Test with acaricides against the brown wheat mite. J. Econ Entomol., 48 : 157-161.

3. Mani, S. K. and T. K. Chattopadhayaya. 2003. Plant growth and flower production in rose cultivars under acaricide treatments. Orissa J. Horti., 31(2): 58-61.

4. Nangia, N. and G. P. Channa Basavanna. 1983. Effect of sulphur and dicofol on Tetranychus ludeni and its predator Amblyseius tetranychivorus. The $10^{\text {th }}$ International Cong. Plant Protec. Volume 3 Proc. Conf. Brighton, England, 20-25 November, 1983 Plant protect. For human welfare. 1983, 1028.

5. Rote, N. B., A. H. Shah and N. P. Mehta. 1981. Efficacy of sulphur against Tetranychus cinnabarinus on Hybrid-4 cotton. Acarology-Newsletter, 1: (10): 1-2.

6. SAS Institute. 1988. SAS/STAT User`s Guide, Ver. 6.03. SAS Institute Inc., Cary, North Carolina.

7. Wafa, A. K., M. A. Zaher and A. A. Yousef. 1968. Survey of the tenuipalpid in UAR. Bull. Zool. Soc. Egypt, 22: 52-59. 


\section{تقييم بعض المركبات الكيمائيية وإلحيوية علي العنكبوت الأحمر علي نباتات القطن تحت الظروف الحقلية}

محمد رجائي عبد القادر عباسي'و سعيد عبد العظيم مصطفي ' ومصطفي عبد اللطيف مصطفي'

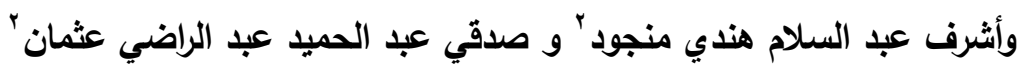

ا ـ كلبة الزراعة- جامعة الأزهر ، القاهن r ـ معهُ بحوث وقاية النباتات- مركز البحوث الزراعية - دقى - جيزة

يعتبر العنكبوت الأحمر العادي من أهم الآفات الأكاروسية التي تصيب نباتات القطن في مصر وقد تم

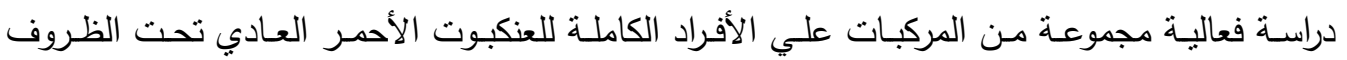

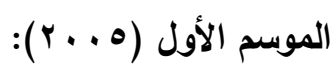

تم رش نباتات القطن بمعدلات مختلفة (ربع حقلي - نصف حقلي - تركيز حقلي) للمركبات الأتية: أجرين ، فيرتميك ، الفلوفينوكسيرون، الهكسافلوميرون، زيت سوبر مصرونا ، الكبريت الميكروني ، الكبريت السائل لدراسة فعالية هذه المركبات علي العنكبوت الأحمر العادي.

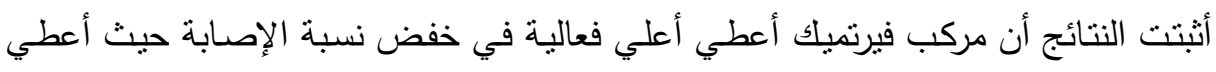

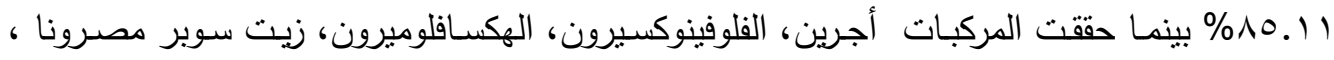

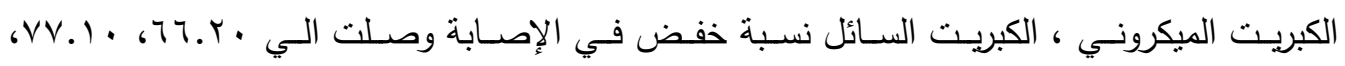

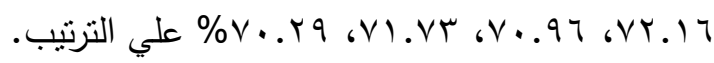

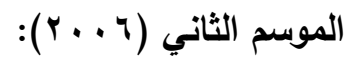

تم تكرار رش نباتات القطن بمعدلات مختلفة (ربع حقلي - نصف حقلي - نركيز حقلي)

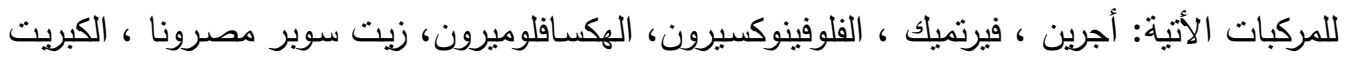

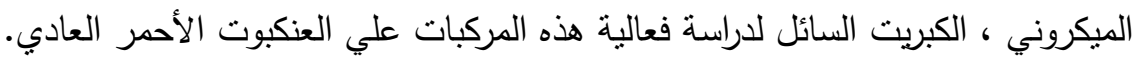

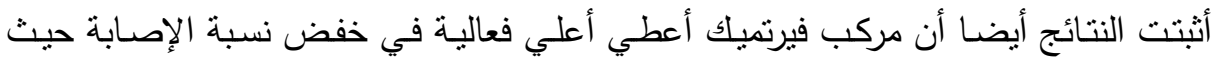

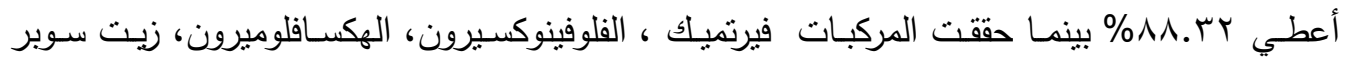

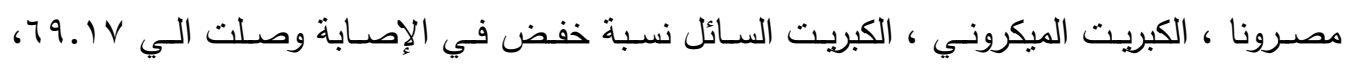

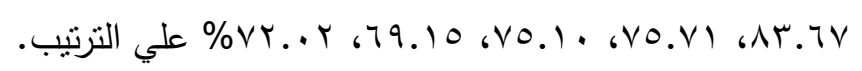

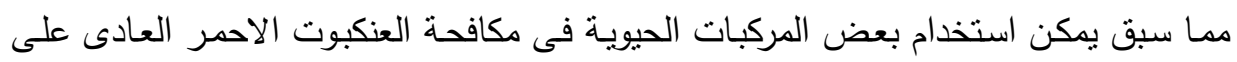
نباتات القطن من خلال برامج المكافحة المتكاملة. 